lation by chemical messengers between organs in plants as that found by Prof. Starling and the present writer in the case of the pancreatic secretion in animals seems to be made out. ${ }^{7}$

W. M. BAyliss.

\section{THE PREVENTION OF VENEREAL DISEASES.}

$7 \mathrm{HE}$ Executive Committee of the National Council for Combating Venereal Diseases, of which Lord Sydenham is president, has put forth a number of proposals for meeting the danger of a large increase of venereal diseases among the civil population when the troops are demobilised. The Times of November 25, in commenting upon the recommendations, states that there will be about 300,000 infected men on demobilisation. These will be distributed to every part of the British Empire, carrying with them the germs of infection. Rural districts in Great Britain and in the Colonies which have hitherto been free or comparatively free from these diseases will consequently suffer seriously.

There are thirteen proposals of the Executive Committee for preventive and curative treatment, but here it is intended to deal with the third recommendation only, namely, "Some means should be devised whereby medical practitioners are encouraged to diagnose venereal disease in patients, and also to give early preventive treatment." The only meaning which can be attached to this solitary proposal for prophylactic treatment is that the patient, having exposed himself to infection, should (if and when the opportunity offers) apply to a doctor encouraged to diagnose venereal disease, who would tell him what course to pursue to eradicate the disease, or possibly what he might have done to avert infection in the past, or how to avoid it in the future.

Medical science has shown that the two venereal diseases, syphilis and gonorrhœa, are due to specific living germs, which when once they are implanted in the tissues of the body are extremely difficult to eradicate. It is too late in a number of cases to avoid serious consequences if the patient has to wait for a diagnosis even by an experienced practitioner, although modern improved methods of curative treatment can do much. If science be consulted rather than sentiment, the earliest treatment would be advocated, such as the use of germicidal disinfectants in portable form as soon after exposure as possible to kill the organisms before they can enter the tissues of the body. This prophylactic treatment was first shown to be effective by experiments on animals, and such a method of prevention applied to human beings, first publicly advocated in a letter to the Times by Sir Bryan Donkin, is supported by a great number of medical authorities. It has long been adopted by the Navy, and has recently been introduced by the Army.

In Public Health, the official organ of the Society of Medical Officers of Health (No. I2,

7 "The Chemical Regulation of the Secretory Process," Proc. Roy. Soc., vol. Ixxiii., p. 3 10. (1904.) NO. 2563 , VOL. IO2] vol. xxxi., September, 1918), there are some interesting and important articles proving the value of earliest treatment in the prevention of venereal disease. Space is too limited to give full details, but the following results speak for themselves: Capt. Walker, of the Canadian Medical Forces, at a conference in Paris, stated that before the introduction of earliest disinfectant treatment the incidence of venereal diseases amongst the 5000 officers and men on leave in Paris during August and September, $19 \mathrm{I} 7$, was 20 per cent. From November, I9I7, to the end of March, 1918, after the introduction of immediate disinfection, only 3 per cent. of infections occurred. Capt. Walker, from his experience, strongly urged (I) prophylaxis for men, (2) prophylaxis for women, (3) a separation of the moral from the medical side of the question.

Likewise the experience of Col. Elgood at Port Said, and of the Australian and New Zealand forces, shows that this earliest disinfection is the most efficient, though not absolutely efficient, method of preventive treatment, because neither drunkenness nor indifference and carelessness on the part of the individual can be controlled. The arguments against the application of this earliest treatment to the civil population are twofold: (I) The injury to the individual and collective moral sense; (2) the impossibility of inducing the local authorities to advocate its practical application. As to these points, we may remark:-

(I) It is doubtful whether the fear of contracting venereal disease quenches the fire of sexual passion of youth or makes the viciously inclined virtuous. Again, there is the sentiment that such measures advocated by public authorities would be an incentive to vice, but against this must be placed the misery and suffering to countless innocent women and children which would arise if an efficacious mode of prevention is rejected upon moral grounds.

(2) During recent times necessity, and alarm for the future of the race, have swept away many prejudices, and, therefore, it is not surprising to find that the Warrington Town Council by a resolution has advocated the adoption of this earliest treatment, and copies of the same were forwarded to the President of the Local Government Board and the councils of the county boroughs of England and Wales. Well may the official journal of medical officers of health, commenting upon this resolution, assert that as a practical preventive measure this is undoubtedly the most important step that has been taken up to the present.

\section{WORK AT THE NATIONAL PHYSICAI, LABORATORY.}

GINCE the opening of the National Physical Laboratory in 1902 remarkable growth has taken place not only in its material resources of buildings and equipment, but also in the number of the staff employed. The Annual Report ${ }^{1}$ recently 1 The National Physical Laboratory. Report for the Year rg17-r8. (H.M. Stationery Office, I9t8.) Price 2s. 6d. net. 